\title{
Inhibition of the Binding of Penicillin to the Pneumococcal Penicillin- binding Proteins (PBPs) by Exogenous Cell Wall Peptides
}

\author{
By ELAINE TUOMANEN* AND STEPHEN SANDE \\ The Rockefeller University, 1230 York Avenue, New York, NY 10021, USA
}

(Received 21 September 1988; revised 18 November 1988; accepted 7 December 1988)

\begin{abstract}
Incubation of pneumococci with D-alanine-containing peptides naturally occurring in peptidoglycan protected cells against lysis and killing by $\beta$-lactam antibiotics near MIC. Such peptides caused decreased binding of the antibiotic to penicillin-binding proteins (PBPs), primarily PBP 2B. This provides direct evidence in vivo for the hypothesis that $\beta$-lactams act as substrate analogues and identifies PBP $2 \mathrm{~B}$ as a killing target in pneumococci.
\end{abstract}

\section{INTRODUCTION}

All antibacterial effects of $\beta$-lactam antibiotics require the presence of an intact $\beta$-lactam ring. The antibacterial activity of $\beta$-lactams is thought to result from the structural similarity between this moiety and the carboxy-terminal D-alanyl-D-alanine residue of the cell wall precursor disaccharide pentapeptide, which is the natural substrate of the cell wall synthetic enzymes (penicillin-binding proteins - PBPs) (Tipper \& Strominger, 1965, 1968). However, effective competition between the $\beta$-lactam antibiotic and cell wall precursors for binding the PBPs has not been demonstrated in vivo. In this report we demonstrate in growing cells that such a competitive mechanism exists and that its consequences include interference with antibioticinduced bacterial lysis and death.

\section{METHODS}

D-Alanine or D-alanine-containing peptides $\left(0 \cdot 1\right.$ to $5 \mathrm{mg} \mathrm{ml}^{-1}$; Serva) listed in Table 1 were added to cultures of Streptococcus pneumoniae strain R6 (Tomasz \& Waks, 1975a) growing exponentially in a chemically defined medium (Tomasz, 1964). Antibiotics listed in Table 2 were added $15 \mathrm{~min}$ later at concentrations ranging from $1 \times$ to $10 \times$ MIC and culture turbidity and viability were followed over $8 \mathrm{~h}$.

For PBP assays in vivo, culture samples were incubated with D-amino acids for $15 \mathrm{~min}$ at $37^{\circ} \mathrm{C}$. Competition between D-amino acid and penicillin was best demonstrated when the standard PBP assay (Zighelboim \& Tomasz, 1980) was modified such that samples were incubated with $\left[{ }^{3} \mathrm{H}\right]$ benzylpenicillin (ethylpiperidinium salt; obtained from Merck Research Division) at low dose $\left(1.3 \mathrm{kBq}, 0.03 \mu \mathrm{g} \mathrm{ml}^{-1}\right)$ for a short time (3 min) at low temperature $\left(32{ }^{\circ} \mathrm{C}\right)$, and then rapidly chilled on ice. The bacteria were recovered by centrifugation $\left(1100 \mathrm{~g}\right.$ for $15 \mathrm{~min}$ at $\left.4{ }^{\circ} \mathrm{C}\right)$ and resuspended in $10 \mathrm{~mm}$-sodium phosphate buffer, $\mathrm{pH} 7.0(50 \mu \mathrm{l})$ containing $1 \%$ Sarkosyl NL-97 $(10 \mathrm{~min}$ at $37^{\circ} \mathrm{C}$ ). Lysates were prepared for slab gel electrophoresis as described by Williamson et al. (1980). PBP band densities were determined by scanning densitometry (Helena Instruments).

For PBP assays in vitro, pneumococcal membranes (Williamson et al., 1980) (100 $\mu \mathrm{g}$ protein) in $100 \mu 10 \mathrm{mM}-$ sodium phosphate buffer, $\mathrm{pH} 7.0$, were preincubated with the $\mathrm{D}$-amino acids for $10 \mathrm{~min}$ at $37^{\circ} \mathrm{C}$ followed by $\left[{ }^{3} \mathrm{H}\right]$ penicillin $(13.3 \mathrm{kBq}, 0.006 \mu \mathrm{g})$ for $3 \mathrm{~min}$ at $32{ }^{\circ} \mathrm{C}$. The mixture was chilled and $1 \%$ Sarkosyl (final concentration) was added to stop the acylation reaction. The mixture was prepared for polyacrylamide electrophoresis as described by Williamson et al. (1980).

\section{RESULTS AND DISCUSSION}

Addition of D-alanine to cultures of pneumococci completely prevented the lysis normally induced by $2 \times$ MIC of cephamycin $\mathrm{C}$ and nocardicin A, and lysis due to benzylpenicillin was delayed (Fig. 1). Results were similar for D-alanine-containing peptides (listed in Table 1) but 
Table 1. Quantification of competition between murein peptides and penicillin for binding to pneumococcal PBPs

\begin{tabular}{|c|c|c|c|c|c|c|c|}
\hline \multirow[b]{2}{*}{ Competitor } & \multicolumn{2}{|c|}{ Conen } & \multicolumn{5}{|c|}{$\begin{array}{l}\text { Percentage of control level of } \\
{\left[{ }^{3} \mathrm{H}\right] \text { penicillin binding to PBPs }}\end{array}$} \\
\hline & $\mathrm{mg} \mathrm{ml}^{-1}$ & $\mathrm{~mm}$ & $1 \mathrm{~A}$ & $1 \mathrm{~B}$ & $2 \mathrm{~A}$ & $2 B$ & 3 \\
\hline \multicolumn{8}{|l|}{ Ineffective } \\
\hline L-Ala & 0.5 & $5 \cdot 6$ & 85 & 101 & 84 & 96 & 96 \\
\hline L-Ala-D-Ala & 0.5 & $3 \cdot 1$ & 85 & 97 & 96 & 95 & 99 \\
\hline D-Ala-L-Ala & 0.5 & $3 \cdot 1$ & 74 & 91 & 79 & 95 & 83 \\
\hline \multicolumn{8}{|l|}{ Effective } \\
\hline D-Ala & 0.5 & $5 \cdot 6$ & 79 & 97 & 97 & 28 & 90 \\
\hline D-Ala-D-Ala & $0 \cdot 5$ & $3 \cdot 1$ & 69 & 68 & 59 & 20 & 83 \\
\hline Lysyl-D-Ala-D-Ala & $0 \cdot 2$ & 0.5 & 70 & 53 & 52 & 42 & 93 \\
\hline Lysyl-D-Ala-D-Ala & 0.5 & $1 \cdot 3$ & 14 & $<10$ & 31 & $<10$ & 35 \\
\hline
\end{tabular}

Table 2. Variation in drug and concentration range permissive for prevention of lysis of pneumococci by D-alanine

\begin{tabular}{llcc}
$\begin{array}{c}\text { Antibacterial } \\
\text { agent }\end{array}$ & \multicolumn{1}{c}{$\begin{array}{c}\text { Source } \\
\text { Cephamycin C }\end{array}$} & $\begin{array}{c}\text { MIC } \\
\left(\mu \mathrm{g} \mathrm{ml}^{-1}\right)\end{array}$ & $\begin{array}{c}\text { Multiple of MIC where } \\
1 \mathrm{mg} \mathrm{m}^{-1} \text { D-alanine } \\
\text { could prevent lysis }\end{array}$ \\
$\begin{array}{ll}\text { Cephalosporin C } \\
\text { Penicillin G }\end{array}$ & $\begin{array}{l}\text { Herck, Sharp \& Dohme } \\
\text { Cefoxitin }\end{array}$ & 50 & 2 \\
Cephaloridine & Eli Lilly Roussel & 50 & 2 \\
Piperacillin & Eli Lilly & $0 \cdot 006$ & 1 \\
Nocardicin A & Bristol Myers & $1 \cdot 5$ & 1 \\
& Fujisawa-Smith Klein & $0 \cdot 05$ & 2 \\
& & $0 \cdot 25$ & 2
\end{tabular}

not L-alanine-containing peptides (listed in Table 1). Bacterial viability paralleled the turbidimetric data, indicating that under these conditions antibiotic-induced killing was also prevented (not shown). Each $\beta$-lactam tested appeared to have a specific concentration range near its MIC within which D-alanine could interfere with lysis induction (Table 2). Cephamycin $\mathrm{C}$ exhibited the broadest such range, while penicillin $\mathrm{G}$ demonstrated a very narrow range around the MIC.

Decreasing concentrations $\left(<200 \mu \mathrm{g} \mathrm{ml}^{-1}\right)$ of $\mathrm{D}$-alanine produced progressively shorter delays in $\beta$-lactam-induced lysis (data not shown). On the other hand, increasing the concentration of $\mathrm{D}$-alanine above $2 \mathrm{mg} \mathrm{ml}^{-1}$ stimulated the lytic activity of $\beta$-lactam antibiotics, as has been previously reported (Lark \& Lark, 1961). D-Alanyl-D-alanine was as effective as D-alanine in interfering with cephamycin-C-induced lysis, while L-alanine was completely inactive.

Two mechanisms for the protective effect of $D$-alanine and its peptides against antibioticinduced lysis were tested: (i) interference with the functioning of the autolytic amidase that is essential for lysis; and (ii) interference with the binding of the $\beta$-lactam antibiotics to PBPs. The first mechanism could be excluded since D-alanine-containing peptides had no effect on two amidase-dependent processes: $(a)$ the autolysis of pneumococci in stationary phase (Tomasz \& Waks, 1975b), and (b) lysis by inhibitors of early steps in wall synthesis (data not shown). The Dalanine effect occurred independent of the synthesis of autolysin. For example, cephamycin $\mathrm{C}$ ( $2 \times$ MIC) did not lyse an autolysis-defective derivative of strain R6 (strain lyt 4-4, Tomasz \& Waks, 1975b) in the presence of exogenous autolysin if D-alanine $\left(1 \mathrm{mg} \mathrm{ml}^{-1}\right)$, was also added: $<5 \%$ change in turbidity and $<25 \%$ release of cell wall radiolabel over $4 \mathrm{~h}$ in the presence of D-alanine vs $>90 \%$ and $>95 \%$ respectively for drug alone.

Eighty percent inhibition of $\left[{ }^{3} \mathrm{H}\right]$ penicillin binding to PBP groups 1,2 and 3 occurred at a comparable concentration of about $30 \mathrm{~mm}$ for all $\mathrm{D}$-alanine-containing peptides tested with the 


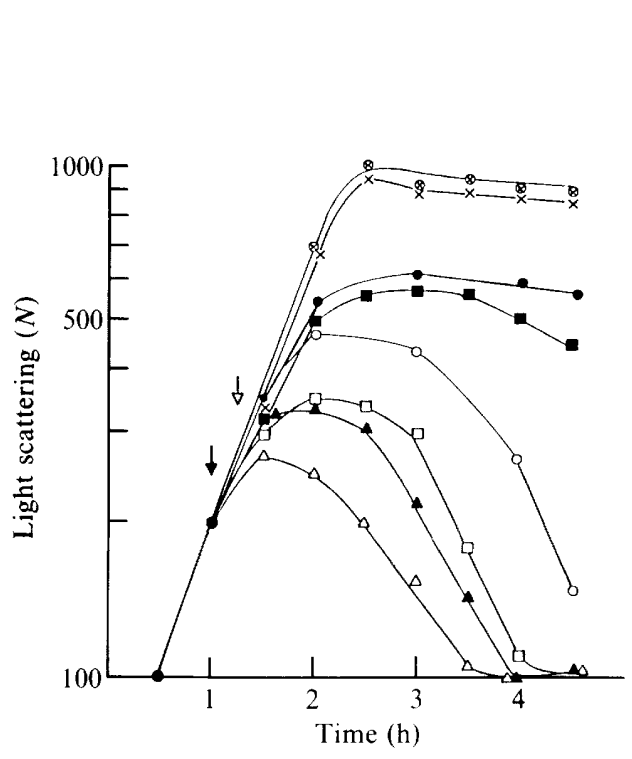

Fig. 1

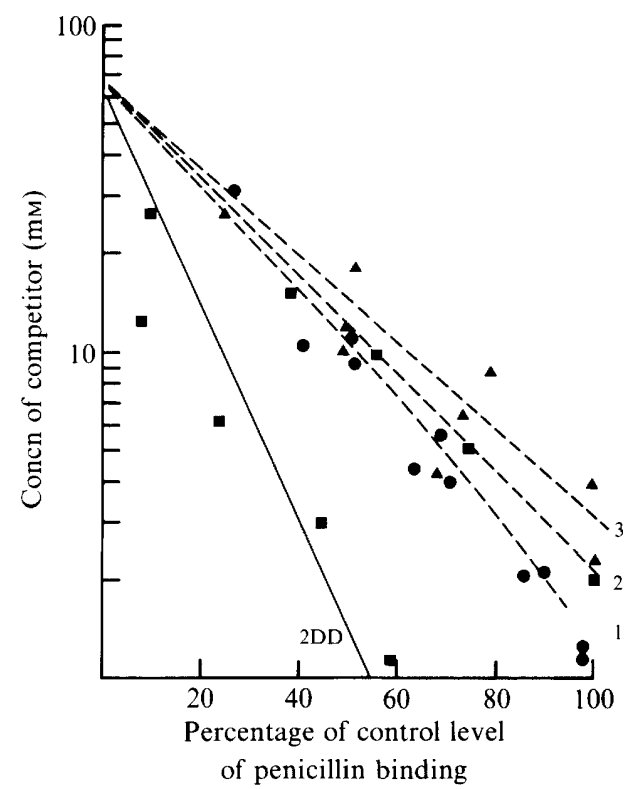

Fig. 2

Fig. 1. D-Alanine protection from lysis by $\beta$-lactam antibiotics. Cultures of $S$. pneumoniae (Tomasz \& Waks, 1975a) were exposed to $1 \mathrm{mg} \mathrm{D}$-alanine $\mathrm{ml}^{-1}$ (filled symbols, added at filled arrow) followed by antibiotic at $2 \times$ MIC (added at open arrow): cephamycin C (squares), nocardicin A (circles), penicillin $G$ (triangles). No antibiotic was added to control cultures $(\otimes$, plus D-alanine. $\times$, minus D-alanine). Representative experiment repeated in triplicate.

Fig. 2. Similarity in the molar concentration of peptides required to inhibit penicillin binding to pneumococcal PBPs 1, 2, 3. Each data point is the mean of triplicate readings of PBP band densities. PBP 1 ; $\square$, PBP $2 ; \triangle$, PBP 3 ; in competition assays with D-alanine, D-alanyl-D-alanine and lysyl-Dalanyl-D-alanine. Regression analysis showed no differences between values except for PBP 2 vs Dalanyl-D-alanine (solid line, 2DD). Each dashed line is the regression line $(90 \%$ confidence limits) calculated for all values for all peptides for an individual PBP (designated by number) except for PBP 2 data plotted as solid line.

exception of the interaction between D-alanyl-D-alanine and PBP 2, where $80 \%$ inhibition was achieved at about $10 \mathrm{~mm}$ (Fig. 2). Similar data were obtained when membrane preparations were used in the competition assays instead of the in vivo labelling of cells.

The protective effect of $D$-alanine derivatives vis-à-vis individual PBPs was demonstrated to be selective (Fig. 3, Table 1). L-Alanine, L-alanyl-D-alanine and D-alanyl-L-alanine had no effect on the binding of $\left[{ }^{3} \mathrm{H}\right]$ penicillin to any of the PBPs. On the other hand, D-alanine and the Dalanine-containing di- or tripeptide suppressed penicillin binding primarily to PBP $2 \mathrm{~B}$ and somewhat less effectively to PBP 1B. The high degree of inhibition of the acylation of PBP 2B (and 1B) strongly suggests that the prevention of penicillin-induced lysis and killing under these conditions is the consequence of this selectivity of the protective effect and indicates that PBP 2B (and, possibly, 1B) is a killing target in pneumococci. This is consistent with the finding that several $\beta$-lactam antibiotics that do not bind to PBP 2B of pneumococci (aziridine ring on the $\mathrm{C} 2$ position in cefotaxime, ceftazidine and azthreonam) cause inhibition of growth without culture lysis (Hakenbeck et al., 1987; Laible \& Hakenbeck, 1987). It is also consistent with the suggestion that PBP 2B may be the rate-limiting enzyme in peptidoglycan synthesis (Williamson \& Tomasz, 1985).

Our interpretation of the PBP-binding experiments is as follows: cell wall peptides form reversible complexes with the PBPs by occupying substrate-specific sites or subsites within the PBPs. This results in a decrease in the fraction of the PBP available for irreversible binding and acylation by the $\beta$-lactam. Competition between $\beta$-lactam antibiotics and peptide substrates 


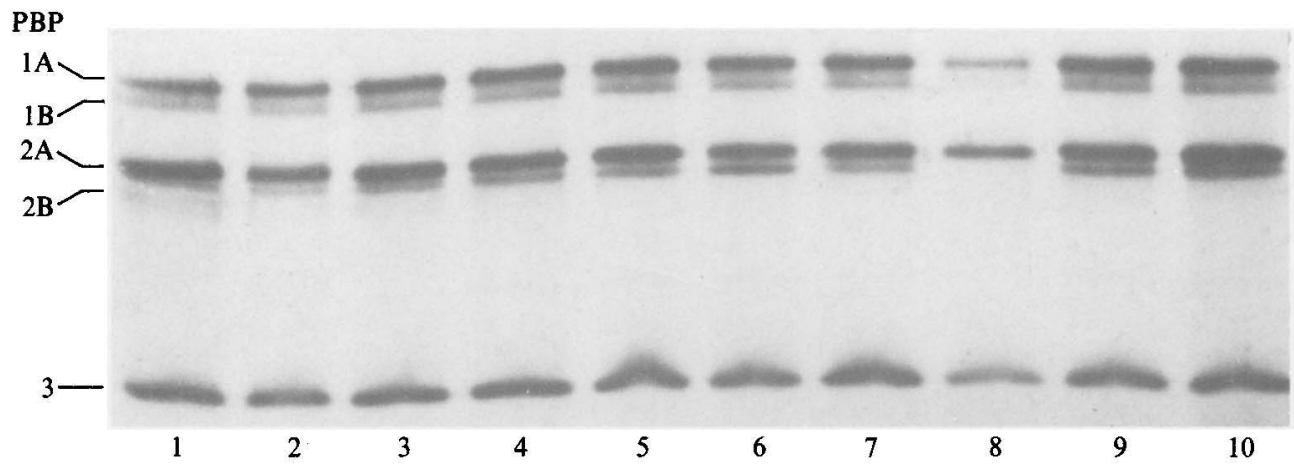

Fig. 3. Titration of in vivo $\left[{ }^{3} \mathrm{H}\right]$ penicillin binding to pneumococcal PBPs in the presence of various alanine-containing peptides. Peptides were used at concentrations of 200 and $500 \mu \mathrm{g} \mathrm{ml}^{-1}$ in the left and right lanes respectively of each pair. Lane 1, D-alanine; lane 2, D-alanyl-D-alanine; lane 3, no peptide; lane 4, D-alanine $\left(500 \mu \mathrm{g} \mathrm{ml}^{-1}\right)$; lanes 5 and 6 , D-alanyl-D-alanine; lanes 7 and 8 , lysyl-D-alanylD-alanine; lanes 9 and 10, L-alanyl-D-alanine. Representative experiment repeated in triplicate.

used in model transpeptidation and carboxypeptidation reactions and catalysed by soluble enzymes has been demonstrated in vitro (Hammes, 1978: Tamura et al., 1976). The lack of competitive inhibition by D-alanyl-L-alanine or L-alanyl-D-alanine in our PBP protection effect shows a striking analogy to the finding that these same peptides had no substrate activity in the model carboxypeptidase assay (Ghuysen et al., 1974). It has also been demonstrated that several radioactively labelled $\beta$-lactam antibiotics and the cell wall peptide analogue diacyl-lysyl-Dalanine-D-alanine-formyl ester bind to the same serine residue at the active site of some bacterial PBPs (Ghuysen et al., 1974). Our observations demonstrate that competition between cell wall peptides and $\beta$-lactam antibiotics occurs in vivo with live, growing bacteria and that this effect can be linked to physiological consequences. The somewhat wider concentration range for cephamycin C and nocardicin A (as compared to benzylpenicillin) within which the protective effect of D-alanine could be demonstrated is presumably due to the fact that these two antibiotics are poor acylating agents and therefore the D-amino acids can compete more effectively (Kunugita et al., 1981; Stapley \& Birnbaum, 1981).

Our finding represents an example of penicillin tolerance arising from modulation of antibiotic effects at the level of bacterial PBPs. A selective tuning down of the antibiotic affinities of 'lytic' PBPs may be the mechanism of the drug-specific tolerance described for a group of clinical pneumococcal strains (Liu \& Tomasz, 1985; Moreillon \& Tomasz, 1988; Tuomanen et al., 1988). It also may explain the protective activity of D-amino acids against $\beta$-lactam-induced lysis of Escherichia coli (Tuomanen \& Tomasz, 1984).

This work was supported in part by an I. T. Hirschl Career Research Award to E. T. and by grants no. RO1 AI16794 and RO1 AI123459 from the National Institutes of Health.

\section{REFERENCES}

Ghuysen, J.-M., Leyh-Bouille, M., Frere, J.-M., Dusart, J., Marquet, A., Perkins, H. \& Nieto, M. (1974). The penicillin receptor in Streptomyces. Annals of the New York Academy of Sciences 235, 236-266.

Hakenbeck, R., Tornette, S. \& Adkinson, N. F. (1987). Interaction of non-lytic beta-lactams with penicillin-binding proteins in Streptococcus pneumoniae. Journal of General Microbiology 133, 755760.

Hammes, W. P. (1978). The LD-carboxypeptidase activity in Gaffkya homari. European Journal of Biochemistry 91, 501-507.
Kunugita, K., Tamaki, S. \& Matsuhashi, M. (1981). Nocardicin A, general aspects and mechanism of action. In Beta Lactam Antibiotics - Mode of Action, New Developments, and Future Prospects, pp. 185197. Edited by M. Salton \& G. D. Shockman. New York: Academic Press.

Laible, G. \& Hakenbeck, R. (1987). Penicillinbinding proteins of beta-lactam-resistant laboratory mutants of Streptococus pneumoniae. Molecular Microbiology 1, 355-363.

LARK, C. \& LARK, K. G. (1961). Studies on the mechanism by which D-amino acids block cell wall synthesis. Biochimica et biophysica acta 49, 308-322. 
LIU, H. \& Tomasz, A. (1985). Tolerance to penicillin in multiply drug-resistant natural isolates of Streptococcus pneumoniae. Journal of Infectious Diseases 152, 365-372.

Moreillon, P. \& Tomasz, A. (1988). Penicillin resistance and defective lysis in clinical isolates of pneumococci: evidence for 2 kinds of antibiotic pressure operating in the clinical environment. Journal of Infectious Diseases 157, 1150-1157.

Stapley, E. \& Birnbaum, J. (1981). Chemistry and microbiological properties of the cephamycins. In Beta Lactam Antibiotics - Mode of Action, New Developments, and Future Prospects, pp. 327-351. Edited by M. Salton \& G. D. Shockman. New York: Academic Press.

Tamura, T., Imae, Y. \& Strominger, J. L. (1976). Purification to homogeneity and properties of two Dalanine carboxypeptidases I from E. coli. Journal of Biological Chemistry 251, 414-423.

TiPPER, D. J. \& STROMINGER, J. L. (1965). Mechanism of action of penicillins: a proposal based on their structural similarity to acyl-D-alanyl-D-alanine. Proceedings of the National Academy of Sciences of the United States of America 54, 1133-1141.

TIPPER, D. J. \& STROMINGER, J. L. (1968). Biosynthesis of the peptidoglycan of bacterial cell walls. XII. Inhibition of cross-linking by penicillins and cephalosporins: studies in Staphylococcus aureus in vivo. Journal of Biological Chemistry 243, 3169-3179.

Tomasz, A. (1964). Studies on the competence of Diplococcus pneumoniae in synthetic medium. Bacteriological Proceedings, p. 29.

Tomasz, A. \& WAKs, S. (1975a). Enzyme replacement in a bacterium: phenotypic correction by the experimental introduction of the wild-type enzyme into a live enzyme-defective mutant pneumococcus. Biochemical and Biophysical Research Communications 65, 1311-1319.

TOMASZ, A. \& WAKs, S. (1975b). Mechanism of action of penicillin : triggering of the pneumococcal autolytic enzyme by inhibitors of cell wall synthesis. Proceedings of the National Academy of Sciences of the United States of America 72, 4162-4166.

Tuomanen, E. \& Tomasz, A. (1984). Protection by Damino acids against growth inhibition and lysis caused by beta lactam antibiotics. Antimicrobial Agents and Chemotherapy 26, 414-416.

Tuomanen, E., Pollack, H., Parkinson, A., DavidSON, M., FACKLAM, R., RICH, R. \& ZAK, O. (1988). Microbiological and clinical significance of a new property of defective lysis in clinical strains of pneumococci. Journal of Infectious Diseases 158, 36-43.

Williamson, R. \& TOMASZ, A. (1985). Inhibition of cell wall synthesis and acylation of the penicillin binding proteins during prolonged exposure of growing Streptococcus pneumoniae to benzylpenicillin. European Journal of Biochemistry 151, 475483.

Williamson, R., HAKENBECK, R. \& TOMASZ, A. (1980). The penicillin-binding proteins of Streptococcus pneumoniae grown under lysis-permissive and lysisprotective (tolerant) conditions. FEMS Microbiology Letters 7, 127-131.

Zighelboim, S. \& Tomasz, A. (1980). Penicillinbinding proteins of multiply antibiotic-resistant South African strains of Streptococcus pneumoniae. Antimicrobial Agents and Chemotherapy 17, 434442. 